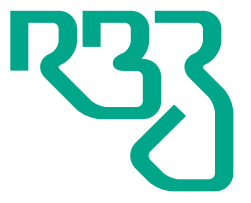

Revista

Brasileira de

Zootecnia

Brazilian Journal of Animal Science

ISSN 1806-9290

www.rbz.org.br

\title{
Growth performance and intestinal health of broilers fed a standard or low-protein diet with the addition of a protease
}

\author{
Kátia Maria Cardinal $^{*}$ (iD), Mariana Lemos de Moraes ${ }^{2}$ (D), Ines Andretta ${ }^{1}$ (DD, \\ Graciele Dalise Schirmann ${ }^{1}$ (iD), Bruna Luiza Belote ${ }^{3}$ (iD, Miguel Alejandro \\ Barrios $^{2}$ iD, Elizabeth Santin ${ }^{3}$, Andréa Machado Leal Ribeiro ${ }^{1}$ iD \\ ${ }^{1}$ Universidade Federal do Rio Grande do Sul, Departamento de Zootecnia, Porto Alegre, RS, \\ Brasil. \\ ${ }^{2}$ Jefo Nutrition Inc., Saint-Hyacinthe, Quebec, Canada. \\ ${ }^{3}$ Universidade Federal do Paraná, Departamento de Medicina Veterinária, Laboratório de \\ Microbiologia e Ornitopatologia, Curitiba, PR, Brasil.
}

*Corresponding author:

katia.zootecnia@hotmail.com

Received: October 25, 2018

Accepted: April 30, 2019

How to cite: Cardinal, K. M.; Moraes, M. L.; Andretta, I.; Schirmann, G. D; Belote, B. L.; Barrios, M. A.; Santin, E. and Ribeiro, A. M. L. 2019. Growth performance and intestinal health of broilers fed a standard or low-protein diet with the addition of a protease. Revista Brasileira de Zootecnia 48:e20180232. https://doi.org/10.1590/rbz4820180232

Copyright: This is an open access article distributed under the terms of the Creative Commons Attribution License (http://creativecommons.org/licenses/by/4.0/), which permits unrestricted use, distribution, and reproduction in any medium, provided the original work is properly cited.
ABSTRACT - We evaluated the effects of a protease supplementation on the growth performance and intestinal health of broilers. Cobb chicks (392; 1-42 d) were divided into four treatments (seven replicates of 14 birds each). There were two feed formulations: a standard diet (SD) and a low crude protein and digestible amino acids diet (Low CP\&AA). The two diets were either supplemented $(+\mathrm{P})$ or not $(-\mathrm{P})$ with a protease (Jefo Protease; $1.25 \mathrm{~g} \mathrm{~kg}^{-1}$ ). Performance was evaluated by feeding phases (1-7, 8-21, 21-35, and 35-42 d). On day 28, ileum samples were analyzed by a morphometric index for histological alterations (I See Inside Scoring System - ISI). Broilers fed the Low CP\&AA had a poor feed conversion ratio (FCR); however, the addition of the protease to the Low CP\&AA positively affected FCR and body weight gain and promoted a performance similar to the group fed SD-P. Birds fed diets supplemented with the protease presented the best ISI morphological index, mainly as a result of the low number of alterations regarding the lamina propria, epithelial thickness, and enterocyte proliferation. It is possible to conclude that the enzyme improves feed conversion and lamina propria, epithelial thickness, and proliferation of enterocytes index of broiler chickens when added to a standard diet or with a low crude protein and digestible amino acids diet.

\section{Introduction}

The constant improvement in performance indexes observed in the poultry production depends on the proper formulation of diets to provide all the necessary nutrients for the chickens. To achieve this goal, increasingly specific diets are formulated and applied, considering growing phase, genetic line, and climate. There is interest in the use of low-crude protein diets to combine productive indexes with economic and environmental advantages. However, when there is reduction of the crude protein (CP) of the diet, some factors must be evaluated, such as the reduction of essential amino acids. The reduction of dietary CP content by $2.5 \%$ compared with the recommended value negatively affects broiler growth performance and blood parameters, but when threonine is included in low-CP diet, weight gain and feed intake (FI) are improved, as well as serum lipid profile (Sigolo et al., 2017). Poultry diets are frequently formulated on a least cost; consequently, feed contains protein from different ingredients and may vary in amino acid bioavailability (Ammerman et al., 1995; Kong and Adeola, 2014). Exogenous 
protease supplementation may improve the utilization of amino acids of the diet (Olukosi et al., 2007; Freitas et al., 2011), and nutritionists can formulate diets with lower levels of dietary protein while maintaining growth performance, promoting sustainability of poultry production in general (Leinonen and Williams, 2015).

The secondary effects of exogenous proteases have been the focus of recent inquiries. Cowieson et al. (2018) concluded that exogenous protease has beneficial effects in combination with ascorbic acid on broiler feed conversion, amino acid digestibility, and intestinal integrity. The mechanisms by which a protease contributes to positive gut health are not entirely clear and may be a combination of different factors (Cowieson and Roos, 2016). Previous researchers have demonstrated that exogenous proteases may contribute to a shift of substrates available in the intestine for bacterial growth (Bedford and Partridge, 2001; Malo et al., 2010). Morphological changes in the intestine are associated with the presence of nutrients in the lumen of the small intestine. The excess of undigested protein relates to putrefaction in the distal portion of the intestine, which can cause proliferation of pathogenic bacteria and increase the incidence of necrotic enteritis (Williams, 2005).

The gut undergoes major morphological and functional modifications after hatching, such as increase in intestine length, villi height and density, and consequently, number of goblet cells, enterocytes, and enteroendocrine cells (Boeli et al., 2002). Transporters present in the membrane of the epithelial cells of the mucosa are responsible for nutrient absorption (Boeli et al., 2002; Pelicano et al., 2003; Khambualai et al., 2010). The presence of inflammation on intestinal mucosa affects broiler weight gain and feed conversion (Kraieski, 2017); therefore, the integrity of the intestine is of fundamental importance, since it is the entry site of nutrients for broiler development.

The objective of this study was to evaluate the impacts of an exogenous protease supplemented to low-protein and low-amino acid diets on performance and intestinal health of broiler chickens.

\section{Material and Methods}

Research on animals was conducted according to the local institutional committee on animal use (case number 33342). The present study was conducted in Porto Alegre, Rio Grande do Sul, Brazil (Latitude: -30.0277 S, Longitude: $-51.228730^{\circ} 1^{\prime} 40^{\prime \prime}$ S, 51ำ13'43" W).

A total of 392 day-old male broilers (Cobb $500 ; \pm 49.5 \mathrm{~g}$ ) were obtained from a commercial hatchery and housed for 42 days in an experimental facility with 28 floor pens of $1 \mathrm{~m}^{2}$ each, covered with wood shavings, and equipped with nipple drinkers and metal hanging feeders. Groups of 14 birds were randomly assigned to one of the 28 pens, and the variation of average body weight to each experimental unit (pen) did not exceed 3\%. Broilers were kept in thermal comfort throughout the trial. Body weight (BW) and FI were measured per feeding phase (1-7, 8-21, 21-35, and 35-42 d) to calculate body weight gain (BWG) and feed conversion ratio (FCR).

Diets based on corn and soybean meal were formulated for four phases (1-7, 7-21, 21-35, and 35-42 d; Table 1). Two different diets were formulated for each phase: a standard diet (SD), according to the nutritional recommendations of the Brazilian Tables for Poultry and Swine (Rostagno et al., 2011) and a low-protein diet (Low CP\&AA), with 6\% reduction on CP and main digestible amino acids (lysine, methionine, threonine, and tryptophan). Each diet formulation was either supplemented (+P) or not $(-\mathrm{P})$ with a protease from Streptomyces griseus (Jefo Protease, Jefo Nutrition Inc., Saint-Hyacinthe, Canada; $1.25 \mathrm{~g} \mathrm{~kg}^{-1}$ ), totaling four treatments in a $2 \times 2$ factorial arrangement. Diets and water were offered ad libitum.

At $28 \mathrm{~d}$, a fragment of approximately $5 \mathrm{~cm}$ length of ileum end portion was collected from seven birds per treatment for intestinal health analysis. The segment was placed on a rectangular piece of cardboard, which was sectioned longitudinally, clipped, washed with saline solution, and immediately stored individually immersed in Davidson solution. The samples were sent to the laboratory to be analyzed macroscopic and microscopically by the ISI ("I See Inside") methodology

R. Bras. Zootec., 48:e20180232, 2019 
(patent INPI UFPR 102015003601 9), which is based on a numeric score of alteration. In this methodology, an impact factor (IF) is defined for each alteration in macroscopic and microscopic analysis, according to the reduction of organ functional capacity, based on previous knowledge from the literature and background research. The IF ranges from 1 to 3 , with 3 being the most impacting to organ function. The parameters evaluated by the ISI methodology were: lamina propria thickness, epithelial thickness, proliferation of enterocytes, epithelial plasma infiltration, mixed inflammatory infiltration in the lamina propria, goblet cell proliferation, congestion, necrosis (apical karyolysis), and presence of Eimeria oocysts.

In addition, the extent of each lesion (intensity) or the observed frequency compared to non-affected organ is evaluated in each organ/tissue with score (S) ranging from 0 to 3: score 0 (absence of lesion or frequency), score 1 (alteration up to $25 \%$ of the area or observed frequency), score 2 (alteration ranging from 25 to $50 \%$ of the area or observed frequency), and score 3 (alteration extends to more than $50 \%$ of the area or observed frequency). To obtain the final value of the ISI index, the IF of each alteration is multiplied by the respective score number, and the results of all alterations are summed according to the formula ISI $=\Sigma(\mathrm{IF} * \mathrm{~S})$. For example, the lamina propria thickness has $\mathrm{IF}=2$, and this number will be multiplied by the observed score (ranging from 1 to 3); if a score $S=3$ (maximum score) is observed for lamina propria thickness in the villi, the ISI for this parameter in the villi will be ISI $=(2 * 3)=6$. The average of 20 villi observed in each bird will reach the final value for this parameter, and the sum of the average of all parameters already mentioned, will give the total ISI value for this specific bird (each bird is a replicate for statistical analysis).

Table 1 - Composition of diets (as fed basis)

\begin{tabular}{|c|c|c|c|c|c|c|c|c|}
\hline \multirow{2}{*}{ Item } & \multicolumn{2}{|c|}{ 1-7 days } & \multicolumn{2}{|c|}{ 7-21 days } & \multicolumn{2}{|c|}{ 21-35 days } & \multicolumn{2}{|c|}{ 35-42 days } \\
\hline & Standard ${ }^{1}$ & $-6 \%{ }^{2}$ & Standard & $-6 \%$ & Standard & $-6 \%$ & Standard & $-6 \%$ \\
\hline \multicolumn{9}{|l|}{ Ingredient $\left(\mathrm{g} \mathrm{kg}^{-1}\right)$} \\
\hline Soybean meal & 396 & 364 & 365 & 329 & 330 & 297 & 295 & 266 \\
\hline Corn & 533 & 572 & 561 & 604 & 591 & 631 & 630 & 665 \\
\hline Soybean oil & 27 & 20 & 34 & 27 & 43 & 37 & 43 & 37 \\
\hline L-lysine & 2 & 2 & 3 & 3 & 2 & 2 & 2 & 2 \\
\hline DL-methionine & 2 & 2 & 1 & 1 & 1 & 1 & 1 & 1 \\
\hline L-threonine & 1 & 0 & 0 & 0 & 0 & 0 & 0 & 0 \\
\hline $\mathrm{NaCl}$ & 5 & 5 & 4 & 4 & 4 & 4 & 4 & 4 \\
\hline Limestone & 5 & 5 & 6 & 6 & 6 & 6 & 6 & 6 \\
\hline Phosphate & 24 & 24 & 19 & 20 & 16 & 16 & 13 & 13 \\
\hline Choline & 0 & 0 & 0 & 0 & 0 & 0 & 0 & 0 \\
\hline Vit-min premix ${ }^{3}$ & 1 & 1 & 1 & 1 & 1 & 1 & 1 & 1 \\
\hline \multicolumn{9}{|c|}{ Nutritional composition ${ }^{4}\left(\mathrm{~g} \mathrm{~kg}^{-1}\right)$} \\
\hline Crude protein & 224.0 & 212.5 & 212.0 & 199.3 & 198.0 & 186.1 & 185.2 & 174.8 \\
\hline ME $\left(\mathrm{kcal} \mathrm{kg}^{-1}\right)$ & 2,960 & 2,960 & 3,050 & 3,050 & 3,150 & 3,150 & 3,200 & 3,200 \\
\hline Dig Lys & 13.2 & 12.5 & 12.8 & 12.0 & 11.3 & 10.6 & 10.6 & 10.0 \\
\hline Dig Met & 5.2 & 4.9 & 4.8 & 4.5 & 4.5 & 4.3 & 4.2 & 4.0 \\
\hline Dig Met+Cys & 9.0 & 8.5 & 8.4 & 8.0 & 8.0 & 7.6 & 7.6 & 7.3 \\
\hline Dig Thr & 8.6 & 8.1 & 7.9 & 7.4 & 7.4 & 6.9 & 6.9 & 6.5 \\
\hline Dig Trp & 2.6 & 2.1 & 2.4 & 2.2 & 2.2 & 2.0 & 2.0 & 1.9 \\
\hline Dig Arg & 14.3 & 13.4 & 13.4 & 12.4 & 12.4 & 11.5 & 11.5 & 10.7 \\
\hline Dig Val & 9.8 & 9.4 & 9.3 & 8.8 & 8.8 & 8.3 & 8.2 & 7.8 \\
\hline
\end{tabular}

${ }^{1}$ Based on the Brazilian Tables for Poultry and Swine (Rostagno et al., 2011).

$26 \%$ reduction of crude protein and digestible amino acids.

${ }^{3}$ Composition (content per kg of diet): 150,000 mg Mn; 100,000 mg Zn; 80,000 mg Fe; 15,000 mg Cu; 1,200 mg I; $700 \mathrm{mg} \mathrm{Se;} \mathrm{23,200,000} \mathrm{IU}$ vitamin A; 5,600,000 IU vitamin D; 52,000 mg vitamin K; 6,000 mg vitamin B1; 18,000 mg vitamin B2; 9,000 mg vitamin B6; $132,000 \mathrm{mg}$ niacin; 44,000 mg panthotenic acid; 2,400 mg folic acid; 200,000 $\mu$ g biotin; 40,000 $\mu$ g vitamin B12.

${ }^{4}$ Nutritional composition was analyzed. 
Each pen was considered an experimental unit and there were seven replicates (pens) per treatment. Data were analyzed by ANOVA using the General Linear Model procedure considering dietary level of protein and supplementation with protease as main factors. In the presence of a significant effect (F), means were separated by Fisher LSD using a statistic software (Statistical Analysis System, version 9.4). For histological analysis, each bird was considered a replicate. At first, data normality was verified using Shapiro-Wilk normality test. Rates were compared using one-way analysis of variance (ANOVA) followed by Tukey's test $(\mathrm{P}<0.05)$. The histological analysis was performed with Statistix 9 software for Windows. Variance analysis was performed considering the following statistical model:

$$
Y_{i j k}=m+\alpha_{i}+\beta_{j}+(\alpha \beta)_{i j}+e_{i j k^{\prime}}
$$

in which $Y_{\mathrm{ijk}}$ is the result, $m$ is the mean of all experimental units for the study variable, $\alpha_{\mathrm{i}}$ is the effect of protease supplementation, $\beta_{\mathrm{j}}$ is the effect of protein level, $(\alpha \beta)_{\mathrm{ij}}$ is the interaction between factors, and $\mathrm{e}_{\mathrm{ij \textrm {k }}}$ is the error associated with observation.

\section{Results}

In the first and second periods of the trial (1-7 and 7-21 d), the enzyme supplementation did not affect performance $(P>0.05)$, whereas Low CP\&AA negatively affected BW, WG, and FCR (Table 2; $\mathrm{P}<0.05)$. Protease supplementation showed the same positive effect from $21 \mathrm{~d}$. In the total period of rearing (1-42 d), WG and FCR were positively influenced by protease, while Low CP\&AA negatively

Table 2 - Growth performance of broilers fed diets containing different protein and digestible amino acid levels supplemented or not with protease

\begin{tabular}{|c|c|c|c|c|c|c|c|}
\hline & \multicolumn{3}{|c|}{ Protein level } & \multicolumn{3}{|c|}{ Protease supplementation } & SEM \\
\hline \multicolumn{8}{|l|}{$1-7 d$} \\
\hline BW $7 \mathrm{~d}$ & 169 & 168 & 0.678 & 168 & 169 & 0.880 & 0.93 \\
\hline FI & 163 & 168 & 0.515 & 168 & 164 & 0.481 & 3.53 \\
\hline BWG & 120 & 119 & 0.631 & 119 & 119 & 0.857 & 0.91 \\
\hline \multicolumn{8}{|l|}{$7-21 d$} \\
\hline BW $21 \mathrm{~d}$ & $861 \mathrm{a}$ & $822 b$ & 0.032 & 839 & 844 & 0.746 & 9.03 \\
\hline FI & 1020 & 1017 & 0.895 & 1009 & 1028 & 0.339 & 9.08 \\
\hline BWG & $692 a$ & $653 b$ & 0.024 & 670 & 675 & 0.741 & 9.05 \\
\hline FI & 2094 & 2144 & 0.363 & 2158 & 2080 & 0.165 & 28.1 \\
\hline BWG & 1282 & 1247 & 0.327 & 1252 & 1277 & 0.473 & 17.0 \\
\hline FCR & $1.63 a$ & $1.72 \mathrm{~b}$ & 0.001 & $1.72 \mathrm{~b}$ & $1.62 \mathrm{a}$ & $<0.001$ & 0.01 \\
\hline \multicolumn{8}{|l|}{$35-42 d$} \\
\hline BW $42 \mathrm{~d}$ & 2792 & 2716 & 0.163 & $2696 b$ & 2811a & 0.040 & 28.2 \\
\hline FI & 1102 & 1110 & 0.902 & 1065 & 1146 & 0.214 & 32.8 \\
\hline BWG & 647 & 646 & 0.974 & $605 b$ & $688 \mathrm{a}$ & 0.018 & 17.8 \\
\hline FCR & 1.83 & 1.72 & 0.876 & 1.76 & 1.66 & 0.071 & 0.02 \\
\hline \multicolumn{8}{|l|}{$1-42 \mathrm{~d}$} \\
\hline
\end{tabular}

BW - body weight; FI - feed intake; BWG - body weight gain; FCR - feed conversion ratio; SEM - standard error of the mean.

${ }^{1}$ Based on the Brazilian Tables for Poultry and Swine (Rostagno et al., 2011).

$26 \%$ reduction of crude protein and digestible amino acids.

${ }^{3}$ P-value of dietary protein level effect.

${ }^{4} \mathrm{P}$-value of protease supplementation effect.

$\mathrm{a}, \mathrm{b}$ - Means followed by different letters differ at $\mathrm{P}<0.05$ by Fisher LSD test. 
influenced FCR $(\mathrm{P}<0.05)$. In the interaction (Table 3), Low CP\&AA-P showed the worst FCR from 7 to 21 and 21 to $35 \mathrm{~d}(\mathrm{P}<0.05)$. Protease supplementation improved FCR $(\mathrm{P}<0.05)$, and the Low CP\&AA-P presented the worst result of FCR in the total period (1-42 d).

To better understand the results, it is important to observe that lower indexes are indicators of better intestinal health (Table 4). Birds fed diet supplemented with protease had the best results for intestinal health index. $(\mathrm{P}<0.05)$. This overall result was mainly due to the effect on lamina propria, epithelial thickness, and proliferation of enterocytes. The reduction on dietary protein negatively $(\mathrm{P}<0.05)$ affected epithelial thickness and epithelial plasma infiltration but promoted better $(\mathrm{P}<0.05)$ index for lamina propria thickness.

The lamina propria thickness had the best index with Low CP\&AA+P treatment, and the epithelial thickness had the worst result with Low CP\&AA-P $(P<0.05$; Table 5). The treatments SD+P and Low $\mathrm{CP} \& A A+P$ presented better index of enterocyte proliferation, while the worst result was observed for the Low CP\&AA-P treatment $(\mathrm{P}<0.05)$. In the sum of the health index of the ileum, we observed that the treatments with protease obtained the best results, and the SD-P diet had a numerally $(\mathrm{P}<0.06)$ worst ileum health index.

Table 3 - Interaction between protein and digestible amino acid levels and protease supplementation on growth performance of broilers

\begin{tabular}{|c|c|c|c|c|c|c|}
\hline Protein level & Standard $^{1}$ & Standard & $6 \%$ reduction ${ }^{2}$ & $6 \%$ reduction & \multirow{2}{*}{$\mathrm{P}^{3}$} & \multirow{2}{*}{ SEM } \\
\hline Enzyme & -Protease & + Protease & -Protease & +Protease & & \\
\hline \multicolumn{7}{|l|}{$1-7 \mathrm{~d}$} \\
\hline BW 7 d & 170 & 169 & 168 & 169 & 0.551 & 1.95 \\
\hline FI & 166 & 162 & 172 & 165 & 0.845 & 5.75 \\
\hline BWG & 120 & 120 & 118 & 120 & 0.530 & 1.98 \\
\hline FCR & 1.37 & 1.35 & 1.45 & 1.38 & 0.617 & 0.03 \\
\hline \multicolumn{7}{|l|}{$7-21 \mathrm{~d}$} \\
\hline BW $21 \mathrm{~d}$ & 876 & 848 & 802 & 842 & 0.066 & 17.8 \\
\hline FI & 1014 & 1027 & 1006 & 1030 & 0.771 & 15.1 \\
\hline BWG & $706 a$ & $679 \mathrm{ab}$ & $635 b$ & $673 \mathrm{ab}$ & 0.050 & 16.4 \\
\hline FCR & $1.44 \mathrm{a}$ & $1.51 \mathrm{a}$ & $1.58 \mathrm{~b}$ & $1.53 a$ & 0.017 & 0.02 \\
\hline \multicolumn{7}{|l|}{$21-35 d$} \\
\hline BW 35 d & 2144 & 2146 & 2040 & 2100 & 0.470 & 22.2 \\
\hline FI & 2095 & 2094 & 2222 & 2067 & 0.165 & 32.2 \\
\hline BWG & 1268 & 1298 & 1237 & 1258 & 0.903 & 19.8 \\
\hline FCR & $1.65 \mathrm{a}$ & $1.61 \mathrm{a}$ & $1.80 \mathrm{~b}$ & $1.64 \mathrm{a}$ & 0.010 & 0.02 \\
\hline \multicolumn{7}{|l|}{$35-42 \mathrm{~d}$} \\
\hline BW $42 \mathrm{~d}$ & 2730 & 2854 & 2664 & 2769 & 0.851 & 42.0 \\
\hline FI & 1010 & 1194 & 1121 & 1100 & 0.122 & 55.7 \\
\hline BWG & 568 & 709 & 624 & 669 & 0.243 & 29.6 \\
\hline FCR & 1.78 & 1.68 & 1.79 & 1.64 & 0.243 & 0.05 \\
\hline \multicolumn{7}{|l|}{$1-42 \mathrm{~d}$} \\
\hline FI & 4284 & 4477 & 4521 & 4361 & 0.064 & 58.2 \\
\hline BWG & 2680 & 2805 & 2615 & 2719 & 0.851 & 36.5 \\
\hline FCR & $1.60 \mathrm{a}$ & $1.60 \mathrm{a}$ & $1.73 \mathrm{~b}$ & $1.60 \mathrm{a}$ & 0.002 & 0.02 \\
\hline
\end{tabular}

BW - body weight; FI - feed intake; BWG - body weight gain; FCR - feed conversion ratio; SEM - standard error of the mean.

${ }^{1}$ Based on the Brazilian Tables for Poultry and Swine (Rostagno et al., 2011).

$26 \%$ reduction of crude protein and digestible amino acids.

${ }^{3} \mathrm{P}$-value of interaction between protein level and protease supplementation.

$\mathrm{a}, \mathrm{b}$ - Means followed by different letters differ at $\mathrm{P}<0.05$ by Fisher LSD test. 
Table 4 - Intestinal health evaluated by the ISI methodology of broilers fed diets containing different protein and digestible amino acid levels supplemented or not with protease

\begin{tabular}{|c|c|c|c|c|c|c|c|c|}
\hline & \multicolumn{4}{|c|}{ Protein level } & \multicolumn{4}{|c|}{ Protease supplementation } \\
\hline & Standard diet ${ }^{1}$ & $6 \%$ reduction ${ }^{2}$ & SEM & $\mathrm{P}^{3}$ & -Protease & + Protease & SEM & $\mathrm{P}^{4}$ \\
\hline Lamina propria thickness & $0.86 \mathrm{~b}$ & $0.60 \mathrm{a}$ & 0.09 & 0.05 & $0.89 \mathrm{~b}$ & $0.58 \mathrm{a}$ & 0.09 & 0.02 \\
\hline Epithelial thickness & $0.06 \mathrm{a}$ & $0.14 \mathrm{~b}$ & 0.03 & 0.04 & $0.14 \mathrm{~b}$ & $0.05 \mathrm{a}$ & 0.03 & 0.03 \\
\hline Proliferation of enterocytes & 0.09 & 0.17 & 0.03 & 0.10 & $0.18 \mathrm{~b}$ & $0.08 \mathrm{a}$ & 0.03 & 0.02 \\
\hline Epithelial plasma infiltration & $0.65 a$ & $0.79 \mathrm{~b}$ & 0.05 & 0.03 & 0.72 & 0.71 & 0.05 & 0.80 \\
\hline $\begin{array}{l}\text { Mixed inflammatory infiltration } \\
\text { in the lamina propria }\end{array}$ & 1.67 & 1.73 & 0.16 & 0.81 & 1.78 & 1.62 & 0.16 & 0.54 \\
\hline Increase of goblet cells & 1.79 & 1.83 & 0.12 & 0.79 & 1.88 & 1.74 & 0.12 & 0.50 \\
\hline Congestion & 0.50 & 0.32 & 0.09 & 0.14 & 0.52 & 0.31 & 0.09 & 0.08 \\
\hline Necrosis/apical karyolysis & 0.13 & 0.05 & 0.05 & 0.28 & 0.07 & 0.12 & 0.05 & 0.56 \\
\hline Presence of oocysts & 0.00 & 0.00 & 0.00 & - & 0.00 & 0.00 & 0.00 & - \\
\hline Total & 5.74 & 5.63 & 0.26 & 0.72 & $6.18 \mathrm{~b}$ & $5.20 \mathrm{a}$ & 0.27 & 0.01 \\
\hline
\end{tabular}

SEM - standard error of the mean.

${ }^{1}$ Based on the Brazilian Tables for Poultry and Swine (Rostagno et al., 2011).

$26 \%$ reduction of crude protein and digestible amino acids.

${ }^{3} \mathrm{P}$-value of dietary protein level effect.

${ }^{4} \mathrm{P}$-value of protease supplementation effect.

$\mathrm{a}, \mathrm{b}$ - Means followed by different letters differ at $\mathrm{P}<0.05$ by Fisher LSD test.

Table 5 - Interaction between protein and digestible amino acid levels and protease supplementation on ileal digestibility coefficients of crude protein and amino acids on intestinal health evaluated by the ISI methodology

\begin{tabular}{|c|c|c|c|c|c|c|}
\hline \multirow{2}{*}{$\begin{array}{l}\text { Protein level } \\
\text { Enzyme }\end{array}$} & \multicolumn{2}{|c|}{ Standard diet ${ }^{1}$} & \multicolumn{2}{|c|}{$6 \%$ reduction ${ }^{2}$} & \multirow{2}{*}{ SEM } & \multirow{2}{*}{$\mathrm{P}^{3}$} \\
\hline & -Protease & + Protease & -Protease & + Protease & & \\
\hline Lamina propria thickness & $0.96 \mathrm{~b}$ & $0.76 \mathrm{~b}$ & $0.82 \mathrm{~b}$ & $0.37 \mathrm{a}$ & 0.09 & 0.02 \\
\hline Epithelial thickness & $0.07 \mathrm{a}$ & $0.04 \mathrm{a}$ & $0.21 \mathrm{~b}$ & $0.07 \mathrm{a}$ & 0.03 & 0.02 \\
\hline Proliferation of enterocytes & $0.13 \mathrm{ab}$ & $0.06 a$ & $0.23 \mathrm{~b}$ & $0.10 \mathrm{a}$ & 0.03 & 0.04 \\
\hline Epithelial plasma infiltration & 0.64 & 0.66 & 0.82 & 0.76 & 0.05 & 0.16 \\
\hline Mixed inflammatory infiltration in the lamina propria & 1.91 & 1.44 & 1.62 & 1.83 & 0.16 & 0.39 \\
\hline Increase of goblet cells & 2.00 & 1.58 & 1.74 & 1.93 & 0.12 & 0.26 \\
\hline Congestion & 0.58 & 0.42 & 0.46 & 0.17 & 0.09 & 0.15 \\
\hline Necrosis/apical karyolysis & 0.09 & 0.17 & 0.05 & 0.05 & 0.05 & 0.60 \\
\hline Presence of oocysts & 0.00 & 0.00 & 0.00 & 0.00 & 0.00 & - \\
\hline Total & 6.38 & 5.13 & 5.95 & 5.29 & 0.26 & 0.06 \\
\hline
\end{tabular}

SEM - standard error of the mean.

${ }^{1}$ Based on the Brazilian Tables for Poultry and Swine (Rostagno et al., 2011).

${ }^{2} 6 \%$ reduction of crude protein and digestible amino acids.

${ }^{3} \mathrm{P}$-value of interaction between protein level and protease supplementation.

$\mathrm{a}, \mathrm{b}$ - Means followed by different letters differ at $\mathrm{P}<0.05$ by Fisher LSD test

\section{Discussion}

The results of growth performance of broiler fed diets with the addition of exogenous proteases is variable, possibly due to differences in laboratory assays and experimental designs, especially in negative control diets (Rutherfurd et al., 2007; Angel et al., 2011; Romero et al., 2014). The effects of protein and amino acid digestibility on growth may be associated to physical and chemical factors of the individual feed ingredients, as granule size and anti-nutritional factors (Romero et al., 2013; Amha et al., 2015). El-Katcha et al. (2014) observed that performance index of broilers was not significantly affected by enzyme supplementation in comparison with the control group. In our trial, there was no difference in FCR between SD-P and SD+P treatments and this may be associated with optimal levels 
of endogenous enzymes, that is, the amount of protease present in the gut was enough to digest the protein. Another hypothesis is that the result may be associated with the adaptation of the animal. Some studies have shown that broilers reduce the endogenous secretion of enzymes when exogenous addition occurs. According to Yuan et al. (2017), broilers fed diet supplemented with 160 and $80 \mathrm{mg} \mathrm{kg}^{-1}$ of protease reduced cholecystokinin and pancreatic trypsin activity.

In this study, an extreme reduction (6\%) of dietary protein and digestible amino acids negatively affected FCR, although, when protease was added, the growth performance results were similar to the standard diets. Rehman et al. (2017) also observed a decrease in body weight of broilers fed diets with protein reduction, and it was associated to the low dietary protein and amino acid concentrations. These authors obtained better results of performance, feed utilization, carcass traits, and nitrogen retention when there was reduction of protein with protease supplementation. According to Cowieson and Roos (2013), when the inherent digestibility of amino acids in the control diet was less than $70 \%$, protease addition improved amino acid digestibility in $90 \%$ of cases with a mean improvement of around $10 \%$. When the inherent digestibility of amino acids in the control diet was more than $90 \%$, there was a protease-mediated improvement in digestibility in only $60 \%$ of cases with a mean improvement of around 2\%. Ghazi et al. (2002) reported that the addition of protease in broiler diet resulted in increased true metabolizable energy, and Yu et al. (2007) observed that supplementation of protease in diets with low $\mathrm{CP}$ can reduce protein waste and nitrogen excretion, without a reduction in broiler performance. Together, these factors may explain why protease improved feed conversion in chickens fed diets with reduced protein.

The Low CP\&AA-P diet had poorer BWG and FCR compared with SD-P during the starter phase (7-21 d), which is a period of increased protein requirements due to muscle deposition. Previous studies reported that growth performance was markedly affected by changes of dietary protein levels, accompanied by varying gastrointestinal digestive enzymes (Liu et al., 2017; Yuan et al., 2017). Wang et al. (2018) observed that protein level has a significant effect on trypsin and chymotrypsin activities in ducks. The addition of the protease (Low CP\&AA+P) compensated the performance losses, resulting in FCR equal to the $\mathrm{SD}+\mathrm{P}$ diet. Based on values of protein digestibility reported in the literature, it can be inferred that a considerable amount of protein passes through the gastrointestinal tract without being completely digested (Lemme et al., 2004; Mahmood et al., 2017). The use of exogenous proteases can enhance endogenous peptidases, improving digestibility of dietary protein and hydrolyzing some anti-nutritional factors, such as antigenic proteins and trypsin inhibitors (Douglas et al., 2000; Ghazi et al., 2002; Yu et al., 2007; Dosković et al., 2013).

Sigolo et al. (2017) reduced $2.5 \%$ in CP and broiler growth performance was negatively affected, but when threonine was included at $110 \%$ of Ross recommendations, in low protein diet, weight gain and FI were increased. Thus, it is possible that the protease added to the Low CP\&AA diet increased threonine availability, consequently, improving feed conversion. Jahanian (2010) reported that threonine supplementation of low-CP diets enhances intestinal health with positive effects on performance. Threonine absorbed is destined to intestinal protein synthesis, which are secreted into the lumen as mucus. Mucins are glycosylated proteins secreted in the intestinal epithelium and are involved in the diffusion and absorption of nutrients along the digestive tract, and mucin also protects the gut from anti-nutritional factors (Schaart et al., 2005; Kim et al., 2007).

The improvement in FCR with the protease addition may be associated with the effect of the enzyme on the improvement in intestinal health of the ileum. Stressors in the digesta can alter the intestinal mucosa, and it is important to pay attention to changes that occur in the gut. Underneath the mucosa, there is a vast surface of epithelial cells of the absorptive type, essential for the transport of nutrients into the enterocytes (Choct, 2009). There are indications that the greater thickness of lamina propria and mucosa is linked to the action of stressors (Silva et al., 2009; Miles et al., 2006). By reducing the lamina propria thickness and the epithelial surface, nutrients can be transported more easily, improving absorption and helping to maintain intestinal health. 
Many factors can affect the microbiota and morphology of the broiler gut, such as diet, management, and challenges (Stanley et al., 2014; Cowieson et al., 2017). Beneficial effects of protease are associated to the amount of undigested nutrients in the ileum, such as protein and starch (Romero et al., 2011; Romero and Plumstead, 2010). Some diet ingredients can produce microbial toxic components, negatively affecting growth performance and nutrient utilization (Rehman et al., 2007). Increased indigestible protein in the hindgut can result in proteolytic fermentation in the ceca of broilers (Wilkie et al., 2005). Depending on the extent of the putrefaction and amino acid composition of the fermented protein, there is a range of potentially harmful consequences (Windey et al., 2012). The metabolic fates of amino acids in enterocytes of the gut mucosa can be manipulated by dietary strategies and suggest that higher concentrations of amino acids in the portal circulation are generated by supplemental rather than protein-bound amino acids (Moss et al., 2018). The use of exogenous protease in this study may be associated with increased availability of protein-bound amino acids. The mechanism that explains how protease acts in intestinal health is unclear. The hydrolysis of antinutritional factors and antigenic proteins are examples of several factors that may influence intestinal health (Ghazi et al., 2002; Cowieson and Roos, 2016). Besides, the intestinal health may be influenced by the reduction of intestinal lumen viscosity (Odetallah et al., 2003), increment of AA availability for mucin synthesis (Cowieson and Roos, 2013), microbiota changes (Windey et al., 2012), and tight junction integrity (Cowieson et al., 2017).

The tendency for increased FI of broilers in the Low CP\&AA-P diet in the overall rearing period may be associated with the aminostatic theory of intake regulation (Gonzales, 2002), in which broilers eat to meet their protein/amino acid requirements first. However, with protease supplementation, FI was decreased, suggesting an improvement in the balance of circulating amino acids. This difference in FI resulted in improved FCR for the protease-supplemented birds. Broilers fed the Low CP\&AA diet had the poorest FCR compared with those fed the other treatments in this study, demonstrating that a $6 \%$ reduction of $\mathrm{CP}$ and amino acids affects growth performance of broilers, but when a protease is supplemented, growth performance may be recovered.

\section{Conclusions}

The use of an exogenous protease can improve feed conversion of broilers. The supplementation of protease positively changes lamina propria, epithelial thickness, and proliferation of enterocytes, resulting in a better intestinal health index.

\section{Conflict of Interest}

The authors declare no conflict of interest.

\section{Author Contributions}

Conceptualization: K.M. Cardinal, M.L. Moraes, I. Andretta, E. Santin and A.M.L. Ribeiro. Data curation: K.M. Cardinal, M.L. Moraes, I. Andretta, G.D. Schirmann, E. Santin and A.M.L. Ribeiro. Formal analysis: K.M. Cardinal, I. Andretta, E. Santin and A.M.L. Ribeiro. Investigation: K.M. Cardinal, M.L. Moraes, I. Andretta and A.M.L. Ribeiro. Methodology: K.M. Cardinal, M.L. Moraes, I. Andretta, B.L. Belote, M.A. Barrios, E. Santin and A.M.L. Ribeiro. Project administration: K.M. Cardinal, I. Andretta and A.M.L. Ribeiro. Supervision: K.M. Cardinal, I. Andretta, B.L. Belote, M.A. Barrios and A.M.L. Ribeiro. Validation: K.M. Cardinal, M.L. Moraes, I. Andretta, B.L. Belote, E. Santin and A.M.L. Ribeiro. Visualization: K.M. Cardinal, M.L. Moraes, I. Andretta and A.M.L. Ribeiro. Writing-original draft: K.M. Cardinal, M.L. Moraes, I. Andretta and A.M.L. Ribeiro. Writing-review \& editing: K.M. Cardinal, I. Andretta and A.M.L. Ribeiro.

\section{References}

Amha, Y. M.; Kumaraswamy, R. and Ahmad F. 2015. A probabilistic QMRA of Salmonella in direct agricultural reuse of treated municipal wastewater. Water Science and Technology 71:1203-1211. https://doi.org/10.2166/wst.2015.093 
Ammerman, C. B.; Baker, D. P. and Lewis, A. J. 1995. Bioavailability of nutrients for animals: Amino acids, minerals, vitamins. Academic Press.

Angel, C. R.; Saylor, W.; Vieira, S. L. and Ward, N. 2011. Effects of a monocomponent protease on performance and protein utilization in 7-to 22-day-old broiler chickens. Poultry Science 90:2281-2286. https://doi.org/10.3382/ps.2011-01482

Bedford, M. R. and Partridge, G. G. 2001. Enzymes in farm animal nutrition. CABI Publishing, Wallingford. p.161-198.

Boeli, I.; Maiorka, A. and Macari, M. 2002. Estrutura funcional do trato digestório. Fisiologia Aviária Aplicada a Frangos de Corte 2:75-98.

Choct, M. 2009. Managing gut health through nutrition. British Poultry Science 50:9-15. https://doi. org/10.1080/00071660802538632

Cowieson, A. J.; Abdollahi, M. R.; Zaefarian, F.; Pappenberger, G. and Ravindran, V. 2018. The effect of a mono-component exogenous protease and graded concentrations of ascorbic acid on the performance, nutrient digestibility and intestinal architecture of broiler chickens. Animal Feed Science and Technology 235:128-137. https://doi.org/10.1016/j. anifeedsci.2017.11.018

Cowieson, A. J.; Zaefarian, F.; Knap, I. and Ravindran, V. 2017. Interactive effects of dietary protein concentration, a mono-component exogenous protease and ascorbic acid on broiler performance, nutritional status and gut health. Animal Production Science 57:1058-1068. https://doi.org/10.1071/AN15740

Cowieson, A. J. and Roos, F. F. 2016. Toward optimal value creation through the application of exogenous mono-component protease in the diets of non-ruminants. Animal Feed Science and Technology 221:331-340.

Cowieson, A. J. and Roos, F. F. 2013. Bioefficacy of a mono-component protease in the diets of pigs and poultry: a meta-analysis of effect on ileal amino acid digestibility. Journal of Applied Animal Nutrition 2:e13. https://doi.org/10.1017/jan.2014.5

Douglas, M. W.; Parsons, C. M. and Bedford, M. R. 2000. Effect of various soybean meal sources and avizyme on chick growth performance and ileal digestible energy. Journal of Applied Poultry Research 9:74-80. https://doi.org/10.1093/japr/9.1.74

Dosković, V.; Bogosavljević-Bosković, S.; Pavlovski, Z.; Milošević, B.; Škrbić, Z.; Rakonjac, S. and Petričević, V. 2013. Enzymes in broiler diets with special reference to protease. World's Poultry Science Journal 69:343-360. https://doi.org/10.1017/ S0043933913000342

El-Katcha, M. I.; Soltan, M. A.; El-Kaney, H. F. and Karwarie, E. R. 2014. Growth performance, blood parameters, immune response and carcass traits of broiler chicks fed on graded levels of wheat instead of corn without or with enzyme supplementation. Alexandria Journal of Veterinary Sciences 40:95-111. https://doi.org/10.5455/ajvs.48232

Freitas, D. M.; Vieira, S. L.; Angel, C. R.; Favero, A. and Maiorka, A. 2011. Performance and nutrient utilization of broilers fed diets supplemented with a novel mono-component protease. Journal of Applied Poultry Research 20:322-334. https://doi.org/10.3382/japr.2010-00295

Ghazi, S.; Rooke, J. A.; Galbraith, H. and Bedford, M. R. 2002. The potential for the improvement of the nutritive value of soya-bean meal by different proteases in broiler chicks and broiler cockerels. British Poultry Science 43:70-77. https://doi.org/10.1080/00071660120109935

Gonzales, E. 2002. Ingestão de alimentos: mecanismos regulatórios. p.187-199. In: Fisiologia aviária aplicada a frangos de corte. 2.ed. Macari, M.; Furlan, R. and Gonzales, E., eds. Funep, Jaboticabal.

Jahanian, R. 2010. Threonine needs of growing broiler chickens for performance and optimum immunological functions in response to dietary crude protein concentration. In: 2nd International Veterinary Poultry Congress, Tehran, Iran.

Khambualai, O.; Yamauchi, K.; Ruttanavut, J.; Incharoen, T. and Kashimura, J. 2010. Effect of sugar cane extract, commercial probiotic and their mixture on growth performance and intestinal histology in broiler chickens. American Journal of Animal and Veterinary Sciences 5:132-138. https://doi.org/10.3844/ajavsp.2010.132.138

Kim, S. W.; Mateo, R. D.; Yin, Y. L. and Wu, G. 2007. Functional amino acids and fatty acids for enhancing production performance of sows and piglets. Asian-Australasian Journal of Animal Science 20:295-306. https://doi.org/10.5713/ ajas.2007.295

Kong, C. and Adeola, O. 2014. Evaluation of amino acid and energy utilization in feedstuff for swine and poultry diets. Asian-Australasian Journal of Animal Sciences 27:917-925. https://doi.org/10.5713/ajas.2014.r.02

Kraieski, A. L. 2017. Desenvolvimento e aplicação de um índice de saúde intestinal para frangos de corte criados em condição experimental e industrial. Dissertação (M.Sc.). Universidade Federal do Paraná, Curitiba.

Leinonen, I. and Williams, A. G. 2015. Effects of dietary protease on nitrogen emissions from broiler production: a holistic comparison using Life Cycle Assessment. Journal of the Science of Food and Agriculture 95:3041-3046. https://doi.org/10.1002/jsfa.7202

Lemme, A.; Ravindran, V. and Bryden, W. L. 2004. Ileal digestibility of amino acids in feed ingredients for broilers. World's Poultry Science Journal 60:423-438. https://doi.org/10.1079/WPS200426

Liu, N.; Wang, J. Q.; Gu, K. T.; Deng, Q. Q. and Wang, J. P. 2017. Effects of dietary protein levels and multienzyme supplementation on growth performance and markers of gut health of broilers fed a miscellaneous meal based diet. Animal Feed Science and Technology 234:110-117. https://doi.org/10.1016/j.anifeedsci.2017.09.013

R. Bras. Zootec., 48:e20180232, 2019 
Mahmood, T.; Mirza, M. A.; Nawaz, H.; Shahid, M.; Athar, M. and Hussain, M. 2017. Effect of supplementing exogenous protease in low protein poultry by-product meal based diets on growth performance and nutrient digestibility in broilers. Animal Feed Science and Technology 228:23-31. https://doi.org/10.1016/j.anifeedsci.2017.01.012

Malo, M. S.; Alam, S. N.; Mostafa, G.; Zeller, S. J.; Johnson, P. V.; Mohammad, N.; Chen, K. T.; Moss, A. K.; Ramasamy, S.; Faruqui, A.; Hodin, S.; Malo, P. S.; Ebrahimi, F.; Biswas, B.; Narisawa, S.; Millán, J. L.; Warren, H. S.; Kaplan, J. B.; Kitts, C. L.; Hohmann, E. L. and Hodin, R. A. 2010. Intestinal alkaline phosphatase preserves the normal homeostasis of gut microbiota. Gut 59:1476-1484. https://doi.org/10.1136/gut.2010.211706

Miles, R. D.; Butcher, G. D.; Henry, P. R. and Littell, R. C. 2006. Effect of antibiotic growth promoters on broiler performance, intestinal growth parameters, and quantitative morphology. Poultry Science 85:476-485. https://doi.org/10.1093/ ps/85.3.476

Moss, A. F.; Sydenham, C. J.; Khoddami, A.; Naranjo, V. D.; Liu, S. Y. and Selle, P. H. 2018. Dietary starch influences growth performance, nutrient utilisation and digestive dynamics of protein and amino acids in broiler chickens offered lowprotein diets. Animal Feed Science and Technology 237:55-67. https://doi.org/10.1016/j.anifeedsci.2018.01.001

Odetallah, N. H.; Wang, J. J.; Garlich, J. D. and Shih, J. C. 2003. Keratinase in starter diets improves growth of broiler chicks. Poultry Science 82:664-670. https://doi.org/10.1093/ps/82.4.664

Olukosi, O. A.; Cowieson, A. J. and Adeola, 0. 2007. Age-related influence of a cocktail of xylanase, amylase, and protease or phytase individually or in combination in broilers. Poultry Science 86:77-86.

Pelicano, E. R. L.; Souza, P.; Souza, H.; Oba, A.; Norkus, E. A.; Kodawara, L. M. and Lima, T. 2003. Morfometria e ultraestrutura da mucosa intestinal de frangos de corte alimentados com dietas contendo diferentes probióticos. Revista Portuguesa de Ciências Veterinárias 98:125-134.

Rehman, H. U.; Vahjen, W.; Awad, W. A. and Zentek, J. 2007. Indigenous bacteria and bacterial metabolic products in the gastrointestinal tract of broiler chickens. Archives of Animal Nutrition 61:319-335. https://doi org/10.1080/17450390701556817

Rehman, Z. U.; Kamran, J.; El-Hack, M. E. A.; Alagawany, M.; Bhatti, S. A.; Ahmad, G.; Saleem, A.; Ullah, Z.; Yameen, R. M. K. and Ding C. 2017. Influence of low-protein and low-amino acid diets with different sources of protease on performance, carcasses and nitrogen retention of broiler chickens. Animal Production Science 58:1625-1631. https://doi.org/10.1071/AN16687

Romero, L. F.; Parsons, C. M.; Utterback, P. L.; Plumstead, P. W. and Ravindran, V. 2013. Comparative effects of dietary carbohydrases without or with protease on the ileal digestibility of energy and amino acids and AMEn in young broilers. Animal Feed Science and Technology 181:35-44. https://doi.org/10.1016/j.anifeedsci.2013.02.001

Romero, L. and Plumstead, P. 2010. Bio-efficacy of feed proteases in poultry and their interaction with other feed enzymes. In: Proceedings of the 24th Australian Poultry Science Symposium, Sydney, New South Wales, Australia.

Romero, L.; Plumstead, P. and Ravindran, V. 2011. Energy contribution of digestible starch, fat, and protein in response to combinations of exogenous xylanase, amylase, and protease in corn-based broiler diets. Poultry Science 90:20.

Romero, L. F.; Sands, J. S.; Indrakumar, S. E.; Plumstead, P. W.; Dalsgaard, S. and Ravindran, V. 2014. Contribution of protein, starch, and fat to the apparent ileal digestible energy of corn-and wheat-based broiler diets in response to exogenous xylanase and amylase without or with protease. Poultry Science 93:2501-2513. https://doi.org/10.3382/ps.2013-03789

Rostagno, H. S.; Albino, L. F. T.; Donzele, J. L.; Gomes, P. C.; Oliveira, R. F.; Lopes, D. C. and Euclides, P. F. 2011. Tabelas brasileiras para aves e suínos. Composição de alimentos e exigências nutricionais. 3. ed. UFV, Viçosa, MG, Brasil.

Rutherfurd, S. M.; Chung, T. K. and Moughan, P. J. 2007. The effect of a commercial enzyme preparation on apparent metabolizable energy, the true ileal amino acid digestibility, and endogenous ileal lysine losses in broiler chickens. Poultry Science 86:665-672. https://doi.org/10.1093/ps/86.4.665

Schaart, M. W.; Schierbeek, H.; Van der Schoor, S. R. D.; Stoll, B.; Burrin, D. G.; Reeds P. J. and Van Goudoever, J. B. 2005. Threonine utilization is high in the intestine of piglets. The Journal of Nutrition 135:765-770. https://doi.org/10.1093/ jn/135.4.765

Sigolo, S.; Zohrabi, Z.; Gallo, A.; Seidavi, A. and Prandini, A. 2017. Effect of a low crude protein diet supplemented with different levels of threonine on growth performance, carcass traits, blood parameters, and immune responses of growing broilers. Poultry Science 96:2751-2760. https://doi.org/10.3382/ps/pex086

Silva, M. A.; Pessotti, B. M. S.; Zanini, S. F.; Colnago, G. L.; Rodrigues, M. R. A.; Nunes, L. C.; Zanini, M. S. and Martins, I. V. F. 2009. Intestinal mucosa structure of broiler chickens infected experimentally with Eimeria tenella and treated with essential oil of oregano. Ciência Rural 39:1471-1477. https://doi.org/10.1590/S0103-84782009005000135

Stanley, D.; Wu, S. B.; Rodgers, N.; Swick, R. A. and Moore, R. J. 2014. Differential responses of cecal microbiota to fishmeal, Eimeria and Clostridium perfringens in a necrotic enteritis challenge model in chickens. PLoS One 9:e104739. https://doi.org/10.1371/journal.pone.0104739

Wang, H.; Zhang, X.; Zhong, S.; Zhu, Y.; Wang, W. and Yang, L. 2018. Effects of crude protein and energy levels on digestive enzyme activities in duck jejunal fluid. Journal of South China Agricultural University 39:5-9. 
Wilkie, D. C.; Van Kessel, A. G.; White, L. J.; Laarveld, B. and Drew, M. D. 2005. Dietary amino acids affect intestinal Clostridium perfringens populations in broiler chickens. Canadian Journal of Animal Science 85:185-193. https://doi. org/10.4141/A04-070

Williams, R. B. 2005. Intercurrent coccidiosis and necrotic enteritis of chickens: rational, integrated disease management by maintenance of gut integrity. Avian Pathology 34:159-180. https://doi.org/10.1080/03079450500112195

Windey, K.; De Preter, V. and Verbeke, K. 2012. Relevance of protein fermentation to gut health. Molecular Nutrition \& Food Research 56:184-196.

Yu, B.; Wu, S. T.; Liu, C. C.; Gauthier, R. and Chiou, P. W. S. 2007. Effects of enzyme inclusion in a maize-soybean diet on broiler performance. Animal Feed Science and Technology 134:283-294. https://doi.org/10.1016/j.anifeedsci.2006.09.017

Yuan, L.; Wang, M.; Zhang, X. and Wang, Z. 2017. Effects of protease and non-starch polysaccharide enzyme on performance, digestive function, activity and gene expression of endogenous enzyme of broilers. PloS One 12:e0173941. https://doi.org/10.1371/journal.pone.0173941 